\title{
Application of natural language processing to the electoral manifestos of social democratic parties in Central Eastern European countries
}

\author{
IVAN BIELIK
}

\section{Sciendo}

Politics in Central Europe (ISSN: 1801-3422)

Vol. 16, No. 1

DOI: $10.2478 /$ pce-2020-0012

\begin{abstract}
The paper examines electoral manifestos of social democratic parties in Visegrad countries through a computer-driven method of content analysis. The analysis focuses on a sentence sentiment (how parties talk about their priorities) and a keyword examination (what parties mostly talk about). Such analysis is not widespread in the academic literature related to Visegrad countries, where a human-based approach to content analysis of electoral manifestos prevails. The paper, however, does not aim to nullify the findings of the previous research, but aims to improve the understanding of the content of manifestos through a different research method. The paper's findings have confirmed the pro-European support of social democratic parties as well as the focus on predominantly socio-economic issues in manifestos. Additionally, the paper explores the effect of incumbency on the manifesto's content. The incumbency seems to have an impact on the manifesto sentiment, but not on keywords.
\end{abstract}

Keywords: natural language processing, political parties, electoral manifestos, social democracy, sentiment analysis, Visegrad countries.

\section{Introduction}

Electoral manifestos are a common subject of political studies. They provide researchers with valuable information about the priorities, goals and intentions of political parties. Many political science projects deal exclusively with them, such as the Manifesto Project, which offers a widely shared coding scheme allowing diverse kinds of analysis. Academic research related to electoral mani- 
festos has come a long way. The content analysis of manifestos started in the 1970s (Volkens - Bara - Budge 2009) and developed into specialised projects that used a common framework for textual analysis (for example, Electoral Studies). Today, comparing and estimating policy positions based on electoral manifestos is quite common in the field of political science. The prevailing method of manifesto research is based on coding procedures, which depend on human judgement. This creates methodological problems, mainly objectivity, reliability and replicability (Rourke - Anderson - Garrison - Archer 2001). All these issues stem from the interpretative nature of coding. In fact, the coding procedures had to improve due to the criticism of their reliability and subjectivity. And the advent of greater computational power has brought new approaches to content analysis. Computer-driven methods have been developed to overcome the likely human bias. The arguments in favour of computer-driven analysis are that it processes large quantities of text faster and more cheaply than humans (Bara 2006) and the outcomes of such analysis are more reliable.

But computer content analysis has flaws as well. The main objection is that it lacks semantic validity. In order to understand the meaning of a text, a researcher must consider its cultural context and socio-economic environment (Volkens - Bara - Budge 2009). Human language is complex for computers to understand (its syntax, semantics and meaning). Computers do not get the right meaning all the time, because words have different meanings in different contexts and are used in idiomatic expressions and irony. ${ }^{1}$

This paper proposes using the computer-driven text analysis of party manifestos to add another layer of understanding to existing research. It is an opportunity to apply new methods to old content and come up with more reliable interpretations. It does not mean that previous academic interpretations and conclusions are obsolete. Natural language processing (hereinafter NLP) has become a useful technique in political science as it might provide new perspectives on the data or to test previous conclusions from other content based methods. This is connected with the availability of digital data (electoral manifestos, official statements, social media posts, etc.) provided by political parties and with the development of software capable of categorising text. NLP relies on increased computing performance to analyse such data. Computers can represent text numerically and analyse it in a way that is difficult for humans. Additionally, the results from NLP methods are quick and reproducible due to computer scripts (or algorithms) available on the Internet. Researchers with similar interests might continue where others have left off.

Computer-driven content analysis is more widespread in Anglo-Saxon countries, due to the quicker computer advances in understanding English as a language. Merz, Regel and Lewandowski (2016) show what is possible with the

1 Idioms and irony are, however, less likely to occur in formal electoral manifestos. 
fully digitalised corpus of manifestos collected by the Manifesto Project. Such data can be used for computing frequencies of texts, tracking policy ideas in manifestos, and even training machine algorithms to automatically code sentences. Slapin and Proksch (2008) propose an algorithm that estimates parties' policy positions based on word frequencies in texts. Having tested it on German political parties' manifestos from 1990 to 2005, they conclude that the algorithm estimated policy positions better than existing time-series estimates. Another aspect of natural language processing is opinion mining and sentiment analysis. Pang and Lee (2008) outline ways of extracting opinion-oriented positions from texts, while Young and Soroka (2012) apply computer-driven sentiment analysis to selected political texts and evaluate the validity of such an approach. Rudkowsky et al. (2018) test a different approach to evaluating sentiment with word embedding. Sentiment analysis has become one of the major areas of research in political communication.

Natural language processing has been little practised on electoral manifestos in Central Eastern Europe. The academic research related to social democratic parties in the region is mostly based on human-based content analysis and expert reviews. Typically, ideology and programmes are analysed only as part of a broader context and often by using case studies or qualitative comparisons (Kopeček 2005; Kopeček 2007; Curry - Urban 2003; White - Lewis - Batt 2013; Bozóki - Ishiyama 2002; Hloušek - Kopeček 2016; Koubek - Polášek 2017; Krašovec - Cabada 2018). The relative lack of a robust methodology influences the theory behind this paper that needs to rely on a general set of assumptions from a wider literature.

This paper aims to analyse the available manifestos of a single social democratic party family. Social democracy is considered one of the general party families in academic literature (Beyme 1985, Mair - Mudde 1998). There is an assumption of a unity in values, positions, and programmatic convergence in each party family (ibid.), something that makes social democratic parties closer to each other than to other political opponents. This party family is also considered one of the most coherent party families in Europe (Hloušek Kopeček 2016). Some empirical observations contradict such close proximity within social democratic party family, at least in Western Europe (Delwit 2005; Keman 2017). Both in domestic politics and at the EU level, social democratic parties have been constrained by diverse economic, social and political reality (Lightfoot 2005). This theoretical contradiction whether social democratic parties are really similar or diverse in their priorities provides a first assumption to check with the analysis of electoral manifestos.

The second theoretical argument for the analysis of social democratic party family is its slow decline in politics. Social democratic parties are still being considered establishment parties ${ }^{2}$. They are connected with the support of lib-

2 At least in European democratic countries. 
eral democracy, the support for equal rights for everyone, the implementation of a welfare state, and moderate policies that avoid extreme, populist solutions (Meyer 2000; Sasoon 2014; Keman 2008). However, they are not as dominant a political force as they were in the past century. Researchers argue that the globalisation of economy and the limitation of powers of a nation state are one of the main reasons for the decline of social democratic parties (Pierson 2001; Thomson 2000; Gallaghan - Tuney 2000, Gallaghan 2000). Thomson (2000) summed up the problem as a social democratic dilemma - it is increasingly hard to achieve the political goals of social democratic parties in a globalised capitalism and international politics. From this point of view, it might be useful to knowhow these global developments are reflected in electoral manifestos and how often parties talk about it. This forms a second assumption of the paper.

The paper focuses its attention to the region of Central Eastern Europe (the Czech Republic, Hungary, Poland and Slovakia). The selected social democratic parties are ČSSD (Czechia), MSZP (Hungary), SLD (Poland) and Smer-SD (Slovakia). These parties have been crucial in the democratic transition and consolidation of democracy in all the selected countries (a slight exception is Smer-SD in Slovakia). They have become well established actors in their domestic political systems but most have been losing political support and impact (except for Smer-SD in Slovakia). The parties share a similar political environment, they are all accepted as members of the Party of European Socialists (PES). Hloušek and Kopeček (2016) have confirmed that their manifesto claims are similar to the ones made in manifestos of PES.

Moreover, these parties have not been widely covered in academic literature when it comes to the computer analysis of their manifestos. The above mentioned analysis by Hloušek and Kopeček (ibid.) used the content analysis of manifestos. This is an opportunity to explore and test the computer-driven method on new cases, and evaluate whether such approaches yield similar results as previous content-based methods. A well-established social democratic agenda in most post-communist countries is generally missing. ${ }^{3}$ Some parties might use a more nationalistic rhetoric or advocate for more protest issues. This makes the situation in the Visegrad countries even more complex for the analysis.

The selection of salient issues depends mostly on important cleavages in society (Lipset - Rokkan 1967; Bartolini - Mair 1990; Bartolinin 2000). Kriesi et al. (2008) argued that with the continuing influence of globalisation the parties have to take a position on socio-economic and cultural issues in the society. This theory is the basis for the examination of how the selected parties, in the framework of social democratic policies, have adapted their electoral strategies in their own political environment, and to study their goals, priorities

3 The exception is the ČSSD party in the Czech Republic, which is considered by many in the academic literature a party with deep historical roots in socialism. 
and intentions, and where they stand between socio-economic and cultural cleavages. The assumption of the paper is that parties in the post-communist democracies would still position themselves mostly on socio-economic issues, not the cultural ones.

\section{Data and methods}

The data for the analysis were obtained from the Manifesto Project. Only manifestos after 2000 could be considered because only they were available as digital texts readable by computers. The table below shows the years for which manifestos were transformed into textual data for each country.

\section{Table 1: List of electoral years for which manifestos were available in computer-readable text}

\begin{tabular}{|l|l|}
\hline Party (Country) & Publication year of party manifesto \\
\hline ČSSD (Czech Republic) & $2002,2006,2010,2013,2017$ \\
\hline MSZP (Hungary) & $2002,2006,2010,2014$ \\
\hline SLD (Poland) & $2001,2007,2011,2016$ \\
\hline Smer-SD (Slovakia) & $2006,2010,2012,2016$ \\
\hline
\end{tabular}

Unfortunately, many Natural Language Processing tools are available only in widely spoken languages (English, French, Chinese, Spanish and German), so once the manifesto texts were ready for analysis, they were translated into English. This brings additional problems in interpreting the results, but no other option was viable. Thus, the text files were translated by Google Translate API into English. The decision was practical due to easy access to the API (application program interface) and the reasonably robust English translation facility that Google has built. The translated texts are not a perfect end product, but they are of sufficient quality to apply selected NLP tools to them.

The NLP analysis focuses on two dimensions of manifestos: sentiment analysis and keywords. Sentiment is used to analyse how parties express their priorities (their way of communication - positive, neutral or negative) and keywords are used to determine what parties talk about the most (the content of their communication). The analysis uses two sentiment analysers, ${ }^{4}$ Textblob and

4 The reason to choose two tools for sentiment analysis is to cover the weaknesses of these tools. It is likely that both tools produce slightly different results because they use various criteria to evaluate 
Vader, applied at the sentence level of the document. Both packages work with a scale from -1.0 to +1.0 , where -1.0 is the most negative and +1.0 is the most positive. The package then evaluates whether a sentence is negative or positive by averaging values of polarity and intensity for each word in the sentence. Sentiment analysers refer to a well-defined lexicon of English words and take values of polarity and intensity from them. ${ }^{5}$ The final interval of a sentence between $[-1.0 ;-0.25]$ means the sentence is negative and the interval $[0.25 ; 1.0]$ means that it is positive. Every sentence outside these intervals is considered neutral. The script then automatically counts the number of sentences in the text, and calculates the ratio positive and negative sentences in a given text.

The paper uses a combination of tools for the keyword analysis too. The selected tools complement each other and can point to different aspects of the manifestos. These tools are listed here:

RAKE $^{6}$ (Rapid Automatic Keyword Extraction) is an algorithm that determines key phrases in a body of text by analysing the frequency of word appearance and its co-occurrence with other words in the text. Ten keywords with the most impact on a selected manifesto are taken into account.

Noun phrase analysis is a part of the Textblob library used for sentiment analysis. It extracts noun phrases from the text and ranks them according to their impact on the text. Nouns usually carry important pieces of information about places, organisations, actions, etc. The extraction of such information from the text is beneficial for the comparison between various manifestos and also among various political parties. Phrases with at least seven occurrences are taken into account.

Frequency distribution counts occurrences of specific words in a text. It is necessary to conduct some text cleaning before running this method on a text. It consists of three steps - make all words lowercase, delete stop words ${ }^{7}$ in a text and lemmatise each word to its lemma according to a dictionary. Words with at least seven occurrences in a manifesto are taken into account.

The Python development environment powered the NLP analysis. All of the code used for the analysis is stored in a public repository on OSF. ${ }^{8}$ Any researcher can download the files and replicate the analysis. ${ }^{9}$

the sentiment of the sentence. Thus by combining the results and making an average from them, the analysis gets a more accurate picture of the sentiment from selected manifestos.

5 More information about this technique is written in this article - https://planspace.org/20150607textblob_sentiment/.

6 The Python package used in the analysis is available at this link- https://pypi.org/project/rake-nltk/.

7 The list of stop words in NLTK package is available at this link - https://gist.github.com/sebleier/554280.

8 Web link: https://osf.io/ndtqg/.

9 This, however, depends on the development environment on the researcher's computer. MacOS/Linux systems share similarities, while Windows has some other commands for dealing with the Python development environment. The analysis for this article was conducted on a Linux machine. 
The questions reflect broad theoretical assumptions from the Introduction section. These assumptions are, in short, as follows:

There is a unity in values, positions, and programmatic convergence in each party family, and social democratic parties are closely related.

Global challenges to social democratic parties are reflected in their manifestos and these parties need to take a position in the face of globalisation in economics and politics.

Parties in opposition use a more critical language in its manifestos, while incumbent parties prefer to mention more positive messages to the electorate.

The electorate of social democratic parties in European post-communist countries still prefers materialistic values (social security, employment, state support) to more post-materialistic values (gender, minorities, environment) as is the case in West-European democracies.

Sentiment and keyword analysis provide a method to answer these assumptions. The analysis of keywords aims at words in a manifesto that either occur very often or have an impact on the composition of the text. This is directly linked to the three assumptions above. A comparison within party manifestos gives an idea of main topics the party advocates. The analysis also evaluates if there are similarities or differences within a group of social democratic parties in the Visegrad countries.

The sentiment analysis provides more data for the third assumption about the difference in sentiment between an incumbent and opposition party. For the effect of incumbency, the analysis adds a categorical variable is_incumbent into the data table with two possible values.

\section{Values Description}

0 the party competed in elections as an opposition party

1 the party held government office at the time of the election

The values were coded based on the historical records of governing coalitions in each state. The variable made it possible to check whether position in the government affects how the party speaks about its electoral priorities. To evaluate this effect, the analysis used a difference of means test (known as a t-test), a standard tool to discover whether differences between groups (measured in averages) could have happened by chance. The null hypothesis against which the test is conducted is that there is no significant difference between the groups. This determines whether there is a significant statistical difference in manifesto sentiment between an incumbent and an opposition party. 
The first automatic objection to this type of research is the small number of cases in the analysis. Elections happen at four or five-year intervals and the selected countries in the analysis have been enjoying democratic regimes only since 1989. Additionally, not all manifestos have been available as digital texts. Thus, the analysis only included 17 manifestos from four countries. Naturally, results from such an analysis cannot be robust and need to be checked in the future with a larger sample. Translating the text into English further limits the value of the analysis as it is prone to changing its structure and meaning. Thus, this paper sets only modest research goals to adapt to this limitation and aims merely to test the new approach to analysis.

Some sources, also, question the usefulness of electoral manifestos as a source of data. It is reasonable to assume that these documents are mostly Public Relations texts aimed at voters, most of whom do not read them. Also, any post-election coalition negotiation alters the electoral priorities of a party, so what is written in the manifesto might not be set in stone. However, this criticism is not directed at the language of the manifestos that is the subject of this paper. Electoral manifestos might not decide election results, but they do reflect how a party expresses its priorities. They aim to convey what parties are trying to achieve and what kind of language they use in public to justify their goals. With that in mind, the paper aims to conduct a comparative analysis of language usage, rather than trying to make a logical link between manifestos and electoral outcomes.

\section{Findings}

The summary of the main findings is discussed below according to the type of analysis. Full tables are included in Appendices and also in the OSF repository ${ }^{10}$.

\section{Keywords analysis}

In the ČSSD manifestos, the expected social democratic themes appeared. ČSSD consistently covered topics such as social policy and social spending (parental allowance, affordable housing and care-giving services) in its manifestos. Together with an emphasis on avoiding social exclusion (measures like indemnity obligation) and preventing negative behaviour (regulation of gambling websites), the party advocated the idea that a state has a legitimate power to regulate social relationships. Additionally, ČSSD consistently emphasised economic development in its manifestos. Ideas such as investment in transportation

10 Web link: https://osf.io/ndtqg/. 
(highways, railways, airports, etc.) and in underdeveloped regions appeared many times. Keywords covering corruption were not covered frequently in the party's official documents during the analysed period. In terms of frequency, the manifestos paid attention to words connected with the Czech state, being in Europe and the management of public services (such as taxation, state support and development). Other topics of the European Left (minority rights, environmental protection and migration) did not appear in the analysis.

The MSZP results were in many areas similar to ČSSD's. What distinguishes this party from ČSSD was its emphasis in its manifestos on agricultural topics. Keywords such as domestic cultivation, programme NATURA 2000, GMO food production, food control and landscape varieties appeared during the analysed period. Social programmes (health care, social security, pensions, subsidised housing), economic incentives (such as investments in roads) and agriculture played the dominant role in MSZP's manifesto keywords. Frequent words related to Hungary and Europe; the use of public powers to support people were also present. MSZP also frequently mentioned the Roma question in its manifestos. Moreover, mentions of FIDESZ and Viktor Orbán increased in the later manifestos. This is most likely connected with the changing status of MSZP in Hungarian politics, which saw the downfall of its electoral preferences and not holding government power.

The SLD manifestos did not confirm the trends set by ČSSD and MSZP. SLD manifesto keywords over time did not form a unified set of ideas. There was no strong theme that ran through all selected manifestos. It seems as if the party was trying to find topics that would attract voters from other parties. Economic regulations were represented by keywords such as bank credit guarantees, carbon emissions, protection against excessive imports, balancing trade and quantitative easing. Pension schemes were mentioned in social policy as well as keywords related to religion, tourism, culture and justice. But these keywords did not appear regularly in its manifestos as opposed to ČSSD or MSZP. Additionally, SLD manifestos stressed international matters such as the Frontex Agency and NATO. In terms of frequency, SLD used similar words to other parties. Words related to Poland and Europe, frequent terms such as state, development, people, health care and non-governmental organisations point to a more standard social democratic agenda.

Smer-SD showed the highest consistency of keywords in its manifestos. Smer-SD used similar wording, topics and some typical social democratic ideas. Keywords connected with economic development and social security have been a standard of the social democratic agenda. Where Smer-SD differed from the other selected parties was in its emphasis on the law and criminal issues. The party tended to emphasise keywords such as sanction regime, criminal code and punishment, restitution claims and constitutional provisions. Moreover, fiscal responsibility also appeared frequently in the manifestos. This was not 
that common among the other selected social democratic parties. Smer-SD, as a Slovak political party, was constrained by Slovakia's membership of the Eurozone and its fiscal rules. Regarding word selection and frequency, Smer-SD consistently used language related to economic development and labour market policies. Words such as social, government, development, state and public often appeared in the results.

\section{Sentiment}

The positive sentiment in ČSSD's manifestos had a greater variation than the negative one. The party was trying to convey more positive messages, in general (approximately one-third of sentences were evaluated as positive). A significant change happened in 2010 when the percentage of positive sentences had dropped and the percentage of negative sentences had increased in comparison with previous elections. This was influenced by the global economic and Eurozone crises, and by the fact that ČSSD was competing in the election as an opposition party. The opposite trend is visible in the 2017 elections when ČSSD was running as an incumbent party and the economy was prospering.

The results for MSZP offer a different picture. The MSZP election manifesto in 2002 had the highest percentage of positive sentences and the lowest percentage of negative ones. The manifesto in 2002 was also relatively short in comparison with later manifestos. From 2002 on, positive sentences decreased, and negative sentences increased. Even though MSZP was part of the government from 2002 to 2010, its manifestos did not contain more positive sentences. Over that time, the change in the sentiment can be linked to MSZP's problems in domestic politics (corruption cases, the rise of other parties and a reputation for incompetence).

SLD is the only party in the selected cases that did not hold government office during the analysed period. Even though SLD tried to form broad left alliances with other leftist parties, such efforts were in vain. SLD contested all elections from 2001 as an opposition party. The election manifesto in 2001, the one before Poland joined the EU, showed the greatest proportion of positivity and smallest amount of negativity compared with the later manifestos. ${ }^{11}$ Additionally, proportion of negative sentences was among the highest in the selected cases.

Slovak party Smer-SD had the most stable results in the group of parties over the analysed period. It was a successful national party that won the largest share of votes in every election from which the data were taken. A low variation among all the manifestos' sentiments means that the content of the election programme did not change much (it is in line with the findings from keyword

11 The only exception in this case was the proportion of negative sentences in the 2016 manifesto that was slightly, but not significantly, lower. 
analysis). Smer-SD stuck with what was apparently working, even when it was in opposition. ${ }^{12}$ Positive sentences make up around $40 \%$ of the manifestos. This is in contrast to the cases of ČSSD and MSZP, which moved from incumbency to opposition with more dramatic changes in their manifestos.

\section{Discussion}

In this part of the paper, the empirical results from the analysis are discussed in the light of the theoretical assumptions stated at the beginning of the paper.

There is a unity in values, positions and programmatic convergence in each party family, and social democratic parties are closely related.

In general, traditional social democratic values are summed up in the values of PES on the European level. These are democracy, freedom, equality, peace, justice ${ }^{13}$. No selected party based its manifesto on protest or criticism of democracy. This is in line with the standard theory of social democratic parties, which assumes that social democratic parties accept the rules of the democratic game and are fully supportive of representative democracy. The pro-European direction of the selected parties was also evident from the analysis. Ideas of Europe and the European Union were present in every manifesto. The references to the EU in observed manifestos reached their peak around the time of accession to the EU in 2004. However, the idea of being in the EU and supporting integration and its values were constant even after accession. This supports the convergence of the selected parties into a unified set of values and positions in their manifestos.

In terms of general electoral priorities, the parties advocated ideas of economic development, social policy and belonging to international institutions such as the EU and NATO. These ideas fit into the typical social democratic agenda throughout Europe. This was confirmed by the keyword and frequency analysis. Topics such as the development of transport, the regulation of housing, unemployment, health care support and education were present, although not evenly, in the analysed manifestos. These topics fall under a general term of socio-economic policy, which is not the political domain of only social democratic parties.

But the variation in the socio-economic issues matters. This was the reason for the keyword and frequency analysis in the paper. The results of the selected parties mostly followed traditional social democratic ideas based on an emphasis on development and growth, state support, the public management of resources and support for the middle class. This is all in line with the theoretical

12 The total number of sentences in Smer-SD manifestos was also consistent. One might assume that they did not change the content of their manifestos significantly. But this is not clear based on the sheer number of sentences in manifestos.

13 The official webpage of PES - https://www.pes.eu/en/about-us/our-values/. 
argument of Hloušek and Kopeček (2016) from the Introduction. But there were also signs of contradiction to a general similarity of social democratic parties. As stated above, Delwit (2005) argued that when one observes priorities of social democratic parties more empirically, there is not a close proximity of these ideas. Lightfoot (2005) also pointed out that these parties are constrained by their own national political realities. These views reflected some observations from the analysis. Mainly, MSZP's emphasis on agriculture and the environment in its keywords or ČSSD's focus on industrial and employment policies rather than on protecting the environment ${ }^{14}$, or the importance of law and order in Smer-SD manifestos. These aspects show the diversity of ideas that the parties work with. Empirically speaking, there is no blueprint for what a social democratic party should put its emphasis on.

Global challenges to social democratic parties are reflected in their manifestos and these parties need to take a position in the face of globalisation in economics and in politics.

The analysis did not provide much evidence in terms of tackling global issues in the selected manifestos or a novelty of ideas. These documents were still mainly oriented towards a national electorate, which is expected. Most frequent words did not mention anything global or international, but state, government, tax and public support. Even capitalism was not a frequent word in manifestos. This leads to the impression that the selected social democratic parties did not aspire beyond their national borders. They just used what had apparently worked in the past. They seemed to hold onto the approach of an independent nation state even though the reality of economic globalisation and internationalisation of politics leaves less and less space for the nation state to act independently. This evolution is not really reflected in the words of the manifestos. At least, the references to the European Union were constant, as mentioned above. This might qualify as a sign that selected social democratic parties looked beyond their national borders.

Additionally, the topic of migration was absent from the results of the analysis. This is a strange observation bearing in mind that migration has been a highly politicised topic in the Visegrad region in recent years. At least three manifestos were expected to be influenced by this topic - ČSSD in 2017, SLD in 2016 and Smer-SD in 2016. But migration was not present as a keyword in any observed manifesto, and words related to migration were not even represented among the most frequent words. Two explanations might be possible. First, the manifestos really did not have significant mentions of the topic of migration. Parties might have used other communication channels to state their position on the topic (TV debates, interviews or social media posts) that they deemed to

14 This might be in line with its electoral strongholds in the north-east industrial regions of the Czech Republic, but not with the general direction of social democracy in Europe. 
be more effective. Second, the most frequent words in mentioned manifestos were not related to security issues at all. But given the saliency of the issue in political agenda-setting, the result of the analysis seems counter-intuitive.

This observation is in line with the general theory behind the relative decline of electoral support for the social democratic parties. As Thomson (2000) coined the term 'social democratic dilemma', the selected parties in the analysis found it hard to react promptly to a changing global environment. Their manifestos looked like relics of the past. Nowadays, many areas of economic and social policy are constrained by global forces beyond the nation state. But it seems that according to the manifestos of the parties in four post-communist countries in Central-Eastern Europe, they have not started to reflect upon it. If the theory about the decline of social democratic parties has some predictive power, the selected parties will find it hard to gain a dominant position in national politics unless they change and react to the issues arising from the globalisation.

Parties in opposition use a more critical language in its manifestos, while incumbent parties prefer to mention more positive messages to the electorate.

Most of the sentences in the manifestos tended to be positive or neutral. Only once did the proportion of negative sentences in a manifesto exceed $10 \%$. The small proportion of negative sentences in manifestos also points to the pro-system character of the social democratic parties, or at least to a lack of opposition to a democratic regime. On average, positive sentiment tended to be higher when the selected party was taking part in an election as an incumbent (39.11\% as incumbent vs $35.21 \%$ as opposition). These numbers, however, do not constitute a causal mechanism. The t-test on positive sentiment between incumbent parties and opposition ones produced a statistically significant result ( $p=0.04$, two-tailed test). The difference in means was therefore not very likely to have been due to chance only. One can assume that this difference probably exists in the populations from which it was drawn. It is reasonable to assume that a party running in an election as an incumbent will present itself with a more positive sentiment in its manifesto.

On the other hand, negative sentiment followed the trend outlined by the positive one, with its values in a different order. Incumbent parties had on average $5.26 \%$ of negative sentiment, and opposition parties scored $7.13 \%$. From the available theory, it is likely that when a social democratic party was in opposition, the ratio of negative words in its manifesto might be expected to be higher than when the same party was incumbent. The difference of means in the case of negative sentiment does not result in a rejection of the t-test's null hypothesis ( $\mathrm{p}=0.1$, two-tailed test). The difference between the mean negative sentiment for incumbent (0.05) and opposition parties $(0.07)$ was narrow. The paper cannot provide statistical evidence that this result was not due to chance only. More data need to be gathered in order to test this hypothesis further. A one-tailed (or directional) test, however, showed a significant level 
$(\mathrm{p}=0.05)$. A directional test only points to a directional relationship between two groups. The null hypothesis is: 'incumbent parties do not score a significantly lower negative sentiment in their manifestos than opposition parties.' Since the p-value was below the expected threshold of 0.05, one can assume that there might be statistically significant lower scores of negative sentiment in incumbent manifestos.

As results of the above-mentioned test, the assumption of the change in a sentiment of an electoral manifesto when being incumbent holds only partially. When taken into an account a positive sentiment, one can observe a statistical significance of change between incumbent and opposition parties, at least on the selected cases in the analysis. Other way around, however, does not fully work. A change in negative sentences in manifestos failed to pass difference of means test. It means that a ration of negative sentences in electoral manifesto is most likely not dependent on the position of the party in government or in opposition. Thus, the stated assumption in the beginning has to be rewritten into a statement similar to this: „Social democratic parties running for an election as an opposition party tend to articulate less amount of positive sentences to their voters as compared to the situation when they run in elections as an incumbent party."

The electorate of social democratic parties in European post-communist countries still prefers materialistic values (social security, employment, state support) to more post-materialistic values (gender, minorities, environment) as is the case in West-European democracies.

The emphasis of the selected parties on the socio-economic policies has already been established above. It is no surprise that social democratic parties deal with the issues of state subsidies, taxation, social benefits, health care, or education. On the other hand, the analysis proved that the post-materialistic dimension of progressive leftist politics was under-represented (issues such as gender equality, environment protection and minority rights) or missing in all observed cases. The keyword analysis of MSZP's manifestos included some mentions of a preservation of land and the Roma minority, but it was an exception from the general rule.

Based on the theory of Kriesi et al. (2008), the economic dimension takes precedence over the cultural one in the selected manifestos. This means that the selected social democratic parties try to focus on the preservation of social achievements and to protect social rights of citizens from the disruptive global market. It also shows where the priorities of a national electorate might lie. Voters still demand an improvement of their economic well-being and the standard social guarantees. This is understandable from the point of view of developing economies. Czech Republic, Hungary, Poland, and Slovakia are catching up with the rest of Western European countries in economic development. This is in contrast with the social democratic electoral priorities in the developed Western 
European democracies. Material well-being and a system of social welfare in these states is already established, so the post-materialistic values can be fully articulated by voters. Therefore, the difference in electoral priorities of parties from the same party family is influenced by the structural conditions in which parties compete for electoral support.

\section{Conclusion}

The aim of the paper was to test the theoretical assumptions related to the social democratic parties in Europe. The paper applied the method of Natural language processing to electoral manifestos. And since the computer-driven content analysis has only been applied minimally to electoral manifestos in Central Eastern Europe, the paper applied a new method on an old content. The results of the analysis, then, served as a check against the already established theory about the social democratic parties. Based on the analysis, the paper concluded the following:

It is not clear if social democratic parties converge in electoral priorities. Here, the theory about the social democratic parties is not unified. Some claim that these parties share a unified set of values and goals, some claim that there are still differences among these parties based on the empirical study of their priorities. The analysis has confirmed both views as valid. It is true that the selected parties, generally, accepted same values, like support for the liberal democracy, the European Union, emphasis on economic development and social policy. However, in terms of electoral solutions to voters, the parties were constrained by their nation-states.

The selected social democratic parties do not aspire for ideas outside of nation-state in their electoral manifestos. On the one hand, this is understandable, because the manifestos are primarily directed to a national electorate. On the other hand, the theory about the decline of social democratic parties argues that these parties need to find ways how to apply their ideas to a new global environment where economic and political forces are oftentimes outside the national borders. Based on the keyword analysis, these parties still rely mostly on the idea of an independent state power to change citizens lives for better.

A significant change in positive sentiment of manifestos happened when social democratic parties run in elections as incumbents. They stressed more positive sentences than when they were in opposition. The change was evaluated by a difference of mean test. However, more observations will be needed in the future to further confirm this conclusion.

Social democratic parties primarily competed on economic issues during election campaigns. The cultural dimension of the social democratic agenda was missing, or it merely appeared. No selected party strongly featured topics like gender equality, environmentalism or minority rights. Also, the topic of 
immigration was excluded from manifestos from 2014 onwards, which seems strange considering the strong opposition to migration in the region during the recent migration crisis in Europe. Based on the theory of political cleavages, these parties and the societies where they compete for votes still hold mostly regards the socio-economic topics as more relevant than the cultural ones.

The NLP method of computer analysis proved to be an useful analytical tool, despite of all its discussed limitations. The method, nevertheless, does bring new perspectives and increases analytical rigour. Sentiment analysis and keyword extractions have found their place in the pursuit of better understanding how political parties shape their electoral manifestos. But while NLP can tell us what was said and how, it cannot tell us why. For this reason, the interpretation of manifestos will still be an important part of political science and should remain an integral part of any computer-powered method of analysing textual data. 


\section{Appendix}

\section{Table: Results of keyword and frequency analysis}

\section{ČSSD}

\begin{tabular}{|c|c|c|c|}
\hline Year & Keywords & Noun phrases & Frequency distribution \\
\hline 2002 & 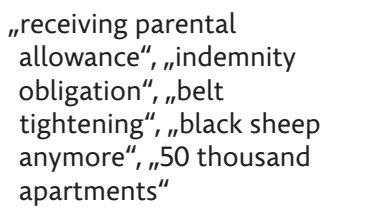 & eu (14), czech (13) & 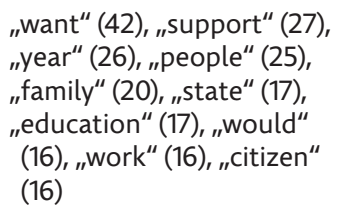 \\
\hline 2006 & $\begin{array}{l}\text { "R6 karlovy vary", } \\
\text { "behavioral disorders", } \\
\text { "minimal added value", } \\
\text { "combating extremist } \\
\text { movements“, "10 } \\
\text { million passengers", } \\
\text { "environmentally friendly } \\
\text { substitutes", "prefabricated } \\
\text { housing estates" }\end{array}$ & $\begin{array}{l}\text { cssd (157), czech (153), eu } \\
\text { (40), european union } \\
\text { (29), europe (17), public } \\
\text { administration (15), health } \\
\text { care (15), economic growth } \\
\text { (13), labor market (12), } \\
\text { roma (12), non-profit } \\
\text { sector (11), non-profit } \\
\text { organizations (11), prague } \\
\text { (10) }\end{array}$ & 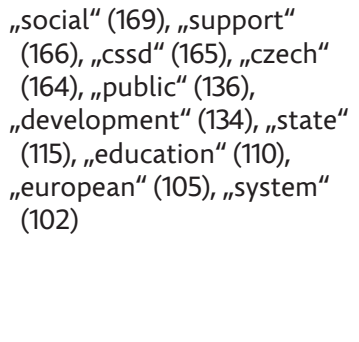 \\
\hline 2010 & 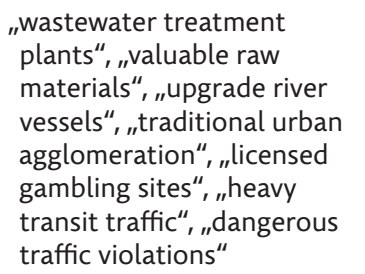 & $\begin{array}{l}\text { czech (57), eu (17), cssd } \\
\text { (16), europe (12), european } \\
\text { union (9) }\end{array}$ & 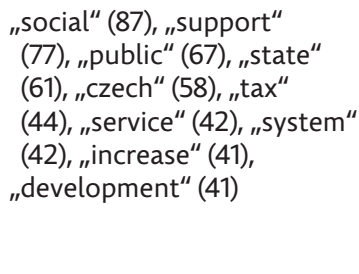 \\
\hline 2013 & $\begin{array}{l}\text { "resisting corrupt pressures", } \\
\text { "4th railway corridors", } \\
\text { "regional differences", } \\
\text { ",liberalized railway market", } \\
\text { "individual constitutional } \\
\text { actors", "socially excluded } \\
\text { localities" }\end{array}$ & $\begin{array}{l}\text { czech (34), european union } \\
\text { (7) }\end{array}$ & 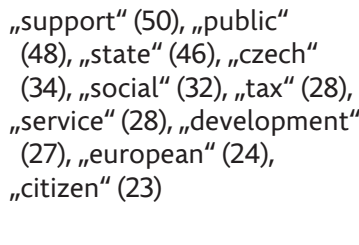 \\
\hline 2017 & $\begin{array}{l}\text { "traditional agricultural } \\
\text { crops", „railway stations", } \\
\text { "gray zones“, ",mental } \\
\text { health centers", ,including } \\
\text { rewarding caregivers", } \\
\text { "television broadcasting act" }\end{array}$ & $\begin{array}{l}\text { czech (65), europe (15), } \\
\text { cssd (10), public services } \\
\text { (10), large companies (8), } \\
\text { european union (8) }\end{array}$ & 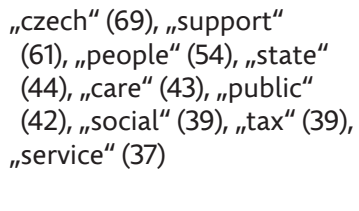 \\
\hline
\end{tabular}




\begin{tabular}{|c|c|c|c|}
\hline Year & Keywords & Noun phrases & Frequency distribution \\
\hline 2002 & $\begin{array}{l}\text { "successful domestic } \\
\text { cultivation", ",obsolete } \\
\text { hospital buildings", } \\
\text { "incentives", }{ }^{\prime \prime} \text { flexible } \\
\text { retirement scheme", "flat } \\
\text { rate optional“, "180 } \\
\text { thousand homes", } \\
\text { "Predictable agricultural } \\
\text { policy" }\end{array}$ & hungarian (8) & 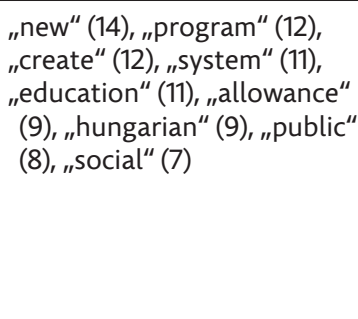 \\
\hline 2006 & $\begin{array}{l}\text { "someone else losing", } \\
\text { "senior citizenship council", } \\
\text { "scale hospital renovations", } \\
\text { "Per capita aid", , ,internet } \\
\text { accessible everywhere" } \\
\text { "blood supply“, "gross } \\
\text { national product" } \\
2000 \text { program" }\end{array}$ & $\begin{array}{l}\text { hungary (52), hungarian } \\
\text { (39), roma (9), eu (8), young } \\
\text { people (7), mszp (7), europe } \\
\text { (7), european union (7) }\end{array}$ & 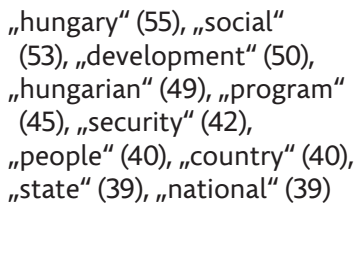 \\
\hline 2010 & $\begin{array}{l}\text { "recorded crimes fell", } \\
\text { "Preventing occasional } \\
\text { infections", }, \text { placing } \\
\text { dangerous foods", } \\
\text { "genetically modified maize" }\end{array}$ & $\begin{array}{l}\text { hungarian (74), hungary } \\
\text { (62), eu (46), roma (30), } \\
\text { young people (18), national } \\
\text { modernization (16), public } \\
\text { education (16), recent years } \\
\text { (13) }\end{array}$ & 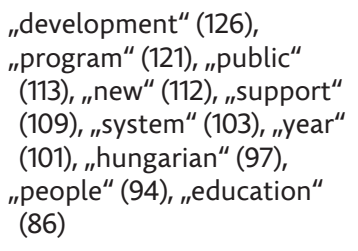 \\
\hline 2014 & $\begin{array}{l}\text { "lease contract", "traditional } \\
\text { landscape varieties", } \\
\text { "secret sound recording", } \\
\text { „scale horticultural farming", } \\
\text { "repair inferior roads", } \\
\text { "locally produced goods", } \\
\text { "frequent extremist } \\
\text { thoughts", }, \text { "declare zero } \\
\text { tolerance" }\end{array}$ & $\begin{array}{l}\text { hungary (73), hungarian } \\
(58), \text { mszp (35), fidesz } \\
\text { (30), hungarians (25), eu } \\
\text { (25), europe (18), offer for } \\
\text { hungary (13), economic } \\
\text { growth (10), young people } \\
\text { (10), orbán (10), labor } \\
\text { market (7) }\end{array}$ & 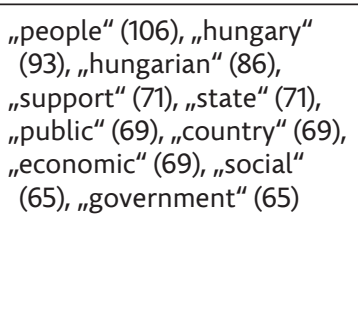 \\
\hline
\end{tabular}


SDL

\begin{tabular}{|c|c|c|c|}
\hline Year & Keywords & Noun phrases & Frequency distribution \\
\hline 2001 & $\begin{array}{l}\text { "sensitivity regarding trade", } \\
\text { "credit guarantee banks", } \\
\text { "counteracts excessive } \\
\text { import" }{ }^{\prime \prime}, \text {,occupational } \\
\text { pension schemes", „'meets } \\
\text { allied standards" }\end{array}$ & $\begin{array}{l}\text { polish (23), poland (19), eu } \\
\text { (12), european union (7) }\end{array}$ & 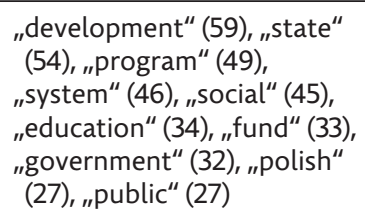 \\
\hline 2007 & $\begin{array}{l}\text { "warsaw frontex agency", } \\
\text { "violent behavioral } \\
\text { patterns", , ,insulting } \\
\text { religious feelings", } \\
\text { "beautiful literature } \\
\text { published" }\end{array}$ & $\begin{array}{l}\text { poland (134), polish ( } 87), \\
\text { european union ( } 25), \\
\text { europe (24), left (21), eu (21), } \\
\text { poles (17), pis (13), medical } \\
\text { services (13), diagnosis } \\
\text { (11), health care system } \\
\text { (10), non-governmental } \\
\text { organizations (10) }\end{array}$ & 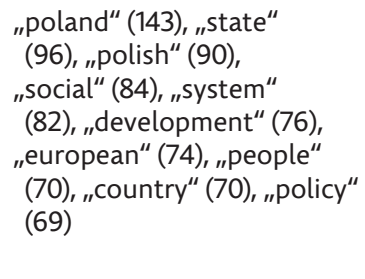 \\
\hline 2011 & $\begin{array}{l}\text { "iustitia", "magnet } \\
\text { attracting tourists", } \\
\text { "urban communication“", } \\
\text { "solid defensive“" ,"night } \\
\text { watchman“ }\end{array}$ & $\begin{array}{l}\text { poland (200), polish (187), } \\
\text { eu (67), diagnosis (54), } \\
\text { left (47), suggestions (46), } \\
\text { local governments (44), } \\
\text { europe (38), young people } \\
\text { (37), poles (35), forces } \\
\text { (33), non-governmental } \\
\text { organizations (33), } \\
\text { european union (32), labor } \\
\text { market (30), state budget } \\
\text { (26), foreign policy (24), } \\
\text { ministry (22), rural areas } \\
\text { (19), internet (19), public } \\
\text { finances (17), education } \\
\text { system (15) }\end{array}$ & 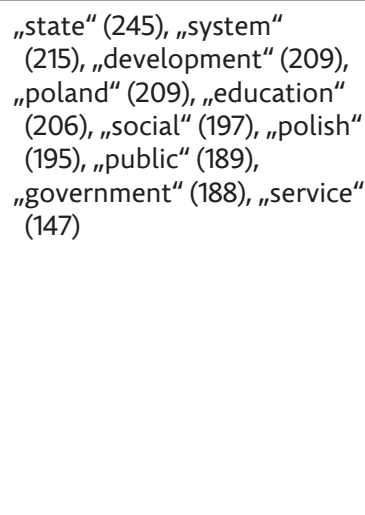 \\
\hline 2016 & $\begin{array}{l}\text { "square postal items", } \\
\text { "north atlantic alliance", } \\
\text { "carbon dioxide emissions", } \\
\text { "called quantitative easing" }\end{array}$ & $\begin{array}{l}\text { poland (69), polish (36), } \\
\text { poles (27), european union } \\
\text { (18), eu (16), support (11), } \\
\text { europe (10) }\end{array}$ & $\begin{array}{l}\text { "state" (101), "people" (77), } \\
\text { "poland" (70), "right" (65), } \\
\text { "social" (64), "public" (63), } \\
\text { "development" (54), ",care } \\
\text { (51), "school" (51), "citizen“ } \\
\text { (48) }\end{array}$ \\
\hline
\end{tabular}




\section{Smer-SD}

\begin{tabular}{|c|c|c|c|}
\hline Year & Keywords & Noun phrases & Frequency distribution \\
\hline 2006 & 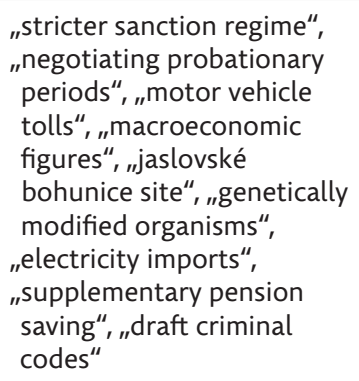 & $\begin{array}{l}\text { smer (118), democracy } \\
\text { (67), social democracy } \\
\text { (61), slovak (59), slovakia } \\
\text { (37), economic growth (11), } \\
\text { european union (11), roma } \\
\text { (10) }\end{array}$ & 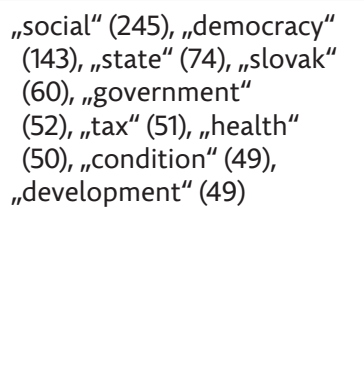 \\
\hline 2010 & $\begin{array}{l}\text { "satisfying restitution } \\
\text { claims", ,facilitate } \\
\text { transitional insolvency", } \\
\text { "danube river basin", } \\
\text { "winning parliamentary } \\
\text { elections", "eliminate } \\
\text { money laundering" }\end{array}$ & $\begin{array}{l}\text { slovak (86), slovakia (64), } \\
\text { eu (61), european union } \\
\text { (17), labor market (13), } \\
\text { government (12), economic } \\
\text { policy (12), sustainable } \\
\text { development (11), economic } \\
\text { growth (10), europe (10) }\end{array}$ & 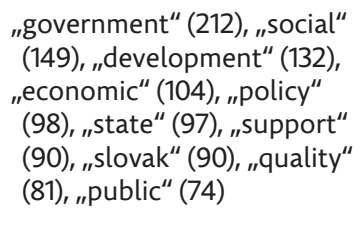 \\
\hline 2012 & $\begin{array}{l}\text { "remove unconstitutional } \\
\text { provisions", ,jaslovské } \\
\text { bohunice site", } \\
\text { "railway", }, \text {,danube river } \\
\text { basin", }{ }^{\prime \prime} \text {,conduct expert } \\
\text { discussions", ,"stricter } \\
\text { punishment mechanisms", } \\
\text { "reduce carbon footprint" } \\
\text { "reduce budget chapters", } \\
\text { "supplementary pension } \\
\text { saving" }\end{array}$ & $\begin{array}{l}\text { slovak (98), slovakia } \\
\text { (63), eu (55), european } \\
\text { union (24), labor market } \\
\text { (14), economic policy } \\
\text { (12), government (11), } \\
\text { sustainable development } \\
\text { (11), economic growth } \\
\text { (11), europe (10), public } \\
\text { administration (10) }\end{array}$ & $\begin{array}{l}\text { "government" (207), } \\
\text { "development" (153), "social“ } \\
\text { (133), „,economic" (109), } \\
\text { "policy“ (107), ",slovak" (102), } \\
\text { "state" (96), ",support" (93), } \\
\text { „public“ (92), "quality“ (87) }\end{array}$ \\
\hline 2016 & 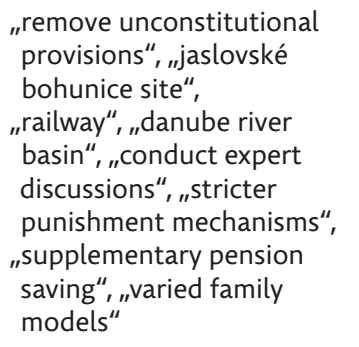 & $\begin{array}{l}\text { slovak (98), slovakia } \\
\text { (61), eu (56), european } \\
\text { union (24), labor market } \\
\text { (15), economic policy (13), } \\
\text { sustainable development } \\
\text { (11), government considers } \\
\text { (11), economic growth } \\
\text { (11), europe (10), public } \\
\text { administration (10) }\end{array}$ & 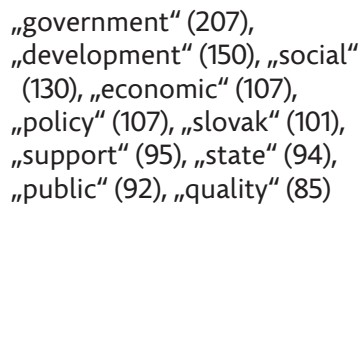 \\
\hline
\end{tabular}


Table: Results of sentiment analysis

ČSSD

\begin{tabular}{|c|c|c|c|c|c|c|c|}
\hline Year & $\begin{array}{c}\text { is_- } \\
\text { incumbent }\end{array}$ & $\begin{array}{c}\text { Share of } \\
\text { votes \% }\end{array}$ & $\begin{array}{c}\text { No of } \\
\text { sentences }\end{array}$ & \% pos & $\begin{array}{c}\text { Pos } \\
\text { election } \\
\text { change }\end{array}$ & \% neg & $\begin{array}{c}\text { Neg } \\
\text { election } \\
\text { change }\end{array}$ \\
\hline 2002 & 1 & 30.2 & 359 & 34.96 & 0.00 & 5.99 & 0.00 \\
\hline 2006 & 1 & 32.3 & 1332 & 39.83 & 4.87 & 5.59 & -0.40 \\
\hline 2010 & 0 & 22.1 & 657 & 33.56 & -6.27 & 8.45 & 2.85 \\
\hline 2013 & 0 & 20.5 & 338 & 36.24 & 2.68 & 6.8 & -1.64 \\
\hline 2017 & 1 & 7.3 & 518 & 42.57 & 6.32 & 5.89 & -0.92 \\
\hline
\end{tabular}

MSZP

\begin{tabular}{|c|c|c|c|c|c|c|c|}
\hline Year & $\begin{array}{c}\text { is_- } \\
\text { incumbent }\end{array}$ & $\begin{array}{c}\text { Share of } \\
\text { votes \% }\end{array}$ & $\begin{array}{c}\text { No of } \\
\text { sentences }\end{array}$ & $\%$ pos & $\begin{array}{c}\text { Pos } \\
\text { election } \\
\text { change }\end{array}$ & \% neg & $\begin{array}{c}\text { Neg } \\
\text { election } \\
\text { change }\end{array}$ \\
\hline 2002 & 0 & 42.1 & 100 & 42.50 & 0 & 2.50 & 0 \\
\hline 2006 & 1 & 43.2 & 588 & 36.73 & -5.77 & 4.17 & 1.67 \\
\hline 2010 & 1 & 19.3 & 1306 & 38.90 & 2.16 & 5.82 & 1.65 \\
\hline 2014 & 0 & 25.6 & 1400 & 28.54 & -10.36 & 8.07 & 2.25 \\
\hline
\end{tabular}

SDL

\begin{tabular}{|c|c|c|c|c|c|c|c|}
\hline Year & $\begin{array}{c}\text { is_- } \\
\text { incumbent }\end{array}$ & $\begin{array}{c}\text { Share of } \\
\text { votes \% }\end{array}$ & $\begin{array}{c}\text { No of } \\
\text { sentences }\end{array}$ & $\%$ pos & $\begin{array}{c}\text { Pos } \\
\text { election } \\
\text { change }\end{array}$ & \% neg & $\begin{array}{c}\text { Neg } \\
\text { election } \\
\text { change }\end{array}$ \\
\hline 2001 & 0 & 41 & 214 & 39.72 & 0 & 6.78 & 0 \\
\hline 2007 & 0 & 13.2 & 797 & 30.80 & -8.92 & 10.41 & 3.64 \\
\hline 2011 & 0 & 8.2 & 1953 & 29.70 & -1.11 & 9.96 & -0.46 \\
\hline 2016 & 0 & 7.6 & 856 & 31.66 & 1.96 & 6.60 & -3.36 \\
\hline
\end{tabular}




\begin{tabular}{|c|c|c|c|c|c|c|c|}
\hline Year & $\begin{array}{c}\text { is_- } \\
\text { incumbent }\end{array}$ & $\begin{array}{c}\text { Share of } \\
\text { votes \% }\end{array}$ & $\begin{array}{c}\text { No of } \\
\text { sentences }\end{array}$ & \% pos & $\begin{array}{c}\text { Pos } \\
\text { election } \\
\text { change }\end{array}$ & \% neg & $\begin{array}{c}\text { Neg } \\
\text { election } \\
\text { change }\end{array}$ \\
\hline 2006 & 0 & 29.1 & 254 & 38.78 & 0 & 6.69 & 0 \\
\hline 2010 & 1 & 34.8 & 579 & 40.93 & 2.15 & 4.75 & -1.94 \\
\hline 2012 & 0 & 44.4 & 578 & 40.57 & -0.36 & 5.02 & 0.27 \\
\hline 2016 & 1 & 28.3 & 596 & 39.85 & -0.72 & 4.61 & -0.40 \\
\hline
\end{tabular}

Definitions of column names:

- is_incumbent - whether or not a party competed in a given elections as an incumbent.

- Share of votes \% - how many per cent the party won nationally in a given election.

- No of sentences - number of sentences in a manifesto.

- \% pos - percentage of positive sentences in a manifesto.

- Pos election change - computed metric showing the increase or decrease of positive sentences in a manifesto compared to the previous one. A positive number means an increase in positive sentences, a negative one means a decrease in positive sentences.

- \% neg-percentage of negative sentences in a manifesto.

- Neg election change - the same principle as with Pos election change; however, a positive number means an increase in negativity and a negative number means a decrease in negativity.

\section{References}

Bara, J. (2006): Do Parties Reflect Public Concerns? In: Bara, J. and Weale, A. (eds.): Democratic Politics and Party Competition. Essays in Honour of lan Budge. London and New York: Routledge. 105-124.

Bartolini, S. (2000). National Cleavage Structures and the Integration Issue Dimension. Paper presented at the Colloque - Science Po. Paris, 26-27 May 2000.

Bartolini, S. - Mair, P. (1990). Identity, Competition, and Electoral Availability: The Stability of European Electorates, 1885-1985. Cambridge: Cambridge University Press.

Bernstein, E. (1899): Die Voraussetzungen des Sozialismus und die Aufgaben der Sozialdemokratie. Stuttgart: J.H.W. Dietz Nachfolg.

Beyme, K. von (1985): Political Parties in Western Democracies. Aldershot: Gower.

Bozóki, A. - Ishiyama, J. T. (2002): The Communist Successor Parties of Central and Eastern Europe. New York: ME Sharpe.

Callaghan, J. T. (2000). The retreat of social democracy. Manchester University Press.

Callaghan, J., \& Tunney, S. (2000). Prospects for Social Democracy: a critical review of the arguments and evidence. Contemporary Politics 6(1): 55-75.

Crosland, C. A. R. (1956): The Future of Socialism. London: Jonathan Cape. 
Curry, J. L. - Urban, J. B. (2003): The Left Transformed in Post-Communist Societies: the Cases of East-Central Europe, Russia, and Ukraine. Lanham: Rowman \& Littlefield.

Däubler, T. - Benoit, K. - Mikhaylov, S. - Laver, M. (2012): Natural Sentences as Valid Units for Coded Political Texts. British Journal of Political Science 42(4): 937-951. doi:10.1017/ S0007123412000105

Delwit, P. (c2005): Social Democracy in Europe. Bruxelles: Editions de l'Université de Bruxelles. Hloušek, V. - Kopeček, L. (2016): Origin, Ideology and Transformation of Political Parties: East-Central and Western Europe Compared. London and New York: Routledge.

Keman, H. (2008). Contemporary approaches to social democracy: Old wines in new bottles. European Political Science 7(4): 494-506. doi: http://dx.doi.org/10.1057/eps.2008. 42.

Keman, H. (2017). Social Democracy: A Comparative Account of the Left-Wing Party Family. Routledge.

Kopeček, L. (2005): Trajectories of the Left: Social Democracy and (Ex-)Communist Parties in Contemporary Europe: Between Past and Future. Brno: CDK.

Kopeček, L. (2007): Politické strany na Slovensku 1989 až 2006. Brno: CDK.

Koubek, J. - Polášek, M. (2017): Strengthening Social Democracy in the Visegrad Countries: The Czech Social Democratic Party. Prague: Friedrich-Ebert-Stiftung e.V. Available at: http://library. fes.de/pdf-files/bueros/prag/13254.pdf (15 September 2019).

Krašovec, A. - Cabada, L. (2018): Adaptability of political parties to the economic and financial crisis? Some evidence from Slovenia and the Czech Republic. Annales, Series Historia et Sociologia 28(4): 865-880, doi: 0.19233/ASHS.2018. 53.

Lightfoot, S. (2005). Europeanizing social democracy?: the rise of the Party of European Socialists. Routledge.

Lightfoot, S. (2005): Europeanizing Social Democracy? The Rise of the Party of European Socialists. London and New York: Routledge.

Lipset, S. M., \& Rokkan, S. (Eds.). (1967). Party systems and voter alignments: Cross-national perspectives (Vol. 7). Free press.

Mair, P. - Mudde, C. (1998): The Party Family and its Study. Annual Review of Political Science, 1(1), 211-229.

Merz, N. - Regel, S. - Lewandowski, J. (2016): The Manifesto Corpus: A New Resource for Research on Political Parties and Quantitative Text Analysis. Research \& Politics 3(2). 2053168016643346.

Meyer, T. - Hinchman, L. (2007): The Theory of Social Democracy. Cambridge: Polity Press.

Meyer, T. (2000). Transformace sociální demokracie: Strana na cestě do 21. století. Brno: Doplněk.

Pang, B. - Lee, L. (2008): Opinion Mining and Sentiment Analysis. Foundations and Trends in Information Retrieval 2(1-2): 1-135.

Pierson, C. (2001). Hard Choices: Social Democracy in the 21st Century. Cambridge: Polity.

Rourke, L. - Anderson, T. - Garrison, D. - Archer, W. (2001): 'Methodological Issues in the Content Analysis of Computer Conference Transcripts.' International Journal of Artificial Intelligence in Education (IJAIED), 12. 
Rudkowsky, E. - Haselmayer, M. - Wastian, M. - Jenny, M. - Emrich, Š. - Sedlmair, M. (2018): More than Bags of Words: Sentiment Analysis with Word Embeddings. Communication Methods and Measures 12(2-3): 140-157.

Sassoon, D. (2014). One hundred years of socialism: the west european left in the twentieth century (New ed.). London: I.B. Tauris.

Slapin, J. B. - Proksch, S. O. (2008): A Scaling Model for Estimating Time-Series Party Positions from Texts. American Journal of Political Science 52(3): 705-722.

Thomson, S. (2000). The Social Democratic Dilemma: Ideology, Governance and Globalization. Springer.

Volkens, A. - Bara, J. - Budge, I. (2009): Data Quality in Content Analysis. The Case of the Comparative Manifestos Project. Historical Social Research / Historische Sozialforschung, 34(1): 234-251.

White, S. - Lewis, P. G. - Batt, J. (eds.). (2013): Developments in Central and East European Politics 5. Basingstoke, Hampshire: Palgrave Macmillan.

Young, L. - Soroka, S. (2012): Affective News: The Automated Coding of Sentiment in Political Texts.' Political Communication 29(2): 205-231.

Zirn, C. - Glavaš, G. - Nanni, F. - Eichorts, J. - Stuckenschmidt, H. (2016): Classifying Topics and Detecting Topic Shifts in Political Manifestos. Proceedings of the International Conference on the Advances in Computational Analysis of Political Text (PolText 2016). 88-93, Dubrovnik, Croatia, 14-16 July 2016.

Ivan Bielik is a PhD student at Masaryk University in Brno. His research topics cover party politics and policy analysis. Email: ivanb@mail.muni.cz 